\title{
Is quantitative assessment of insulin-antibodies and autoantibodies feasible?
}

\author{
M. Koch ${ }^{1}$, J.C.Sodoyez ${ }^{2}$, F.Sodoyez-Goffaux ${ }^{1}$, N.Dozio ${ }^{2}$, L.S. Di Silvio ${ }^{3}$ and A.B. Kurtz ${ }^{3}$ \\ ${ }^{1}$ Department of Pediatrics and ${ }^{2}$ Department of Internal Medicine, University of Liège, Belgium and ${ }^{3}$ The Middlesex Hospital, London, UK
}

\begin{abstract}
Summary. Nine selected sera were studied using radioimmunoassay and enzyme linked immunosorbent assay; eight contained insulin antibodies and were from Type 1 (insulindependent) diabetic patients, one of whom had antibodymediated insulin resistance, and one contained insulin-autoantibodies and was from an asymptomatic blood donor. Sera were assayed in serial dilution to assess their suitability for use as reference standards. Dilution curves were non-parallel in radioimmunoassay but were parallel in immunosorbent assay. In all sera, insulin antibodies were readily detected in both assays whereas the low avidity insulin autoantibodies were only detected by immunosorbent assay and not at all by radioimmunoassay, suggesting that the assays respond differently to antibodies of different avidity. Avidity was estimated in liquid phase from the dissociation rate of preformed complexes of antibody and 125 -iodinated insulin. When high avidity antibodies are used as a reference in radioimmunoassay, lower
\end{abstract}

avidity antibodies are underestimated and vice versa. In contrast, in immunosorbent assay, any serum could be used as a reference regardless of avidity; furthermore competition experiments comparing the highest avidity insulin antibodies, from the insulin-resistant patient, with the insulin autoantibodies from the asymptomatic blood donor yielded nearsuperimposable curves. We conclude that radioimmunoassay is selective for high avidity antibodies whereas enzyme linked immunosorbent assay is not; computer modelling of the two assays supports this conclusion. In practice immunosorbent assay can be standardized using a reference serum, whereas experimental findings and mathematical considerations preclude the use of a standard serum in radioimmunoassay.

Key words: Standardization, insulin-antibodies, insulin-autoantibodies, radioimmunoassay, enzyme linked immunosorbent assay.
Insulin-antibodies (IA) were originally detected in sera from a schizophrenic subject treated by insulin shocks and from Type 1 (insulin-dependent) diabetic patients. The methods used included neutralization of hypoglycaemic activity of insulin [1], passive cutaneous anaphylaxis [2] and binding of tracer amounts of radiolabelled insulin [3, 4]. More recently solid-phase assays were used for IA detection [5-8]. IA have been found using one of these various methods in subjects who have never received insulin and are usually referred to as autoantibodies (IAA) [9-11]; these have been found in the hypoglycaemic autoimmune syndrome [12-17], either spontaneously or in association with drugs, in Type 1 diabetic patients before the onset of the clinical diabetes and in completely normal subjects as will be reported in detail. In the latter two conditions there has been controversy over detection methods as radioimmunoassay (RIA) and enzyme linked immunosorbent assay (ELISA) have given different results as recently reported and discussed $[18,19]$. In a recent workshop, there was not even a consensus as to which sera were positive and which negative. In addition statistical analysis of the results shows clustering of results according to the methodology suggesting that the two techniques measure antibodies differently. These apparent discrepancies prompted the present investigations; the objective was the characterization of reference standards and their assessment for suitability for RIA and ELISA. Mathematical models of the two systems were developed and compared.

\section{Subjects, materials and methods}

\section{Samples}

Eight sera were from insulin-treated diabetic patients one of whom was highly insulin resistant (daily insulin requirement over 200 IU). The sera were previously characterised according to described methods $[8,18,20]$ and selected as representative of a wide range of insulin 


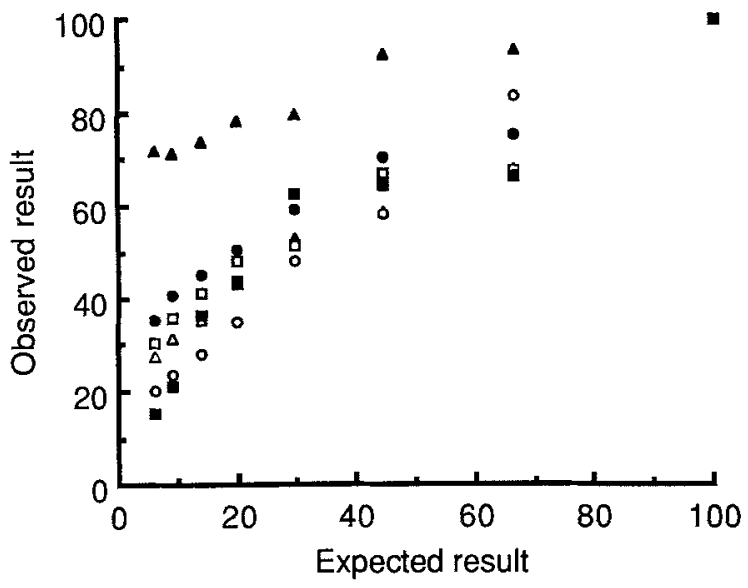

Fig. 1. Dilution curves were constructed for six sera using RIA. Symbols below refer to the various patient sera followed by name abbreviation. One serum was selected as a standard and the other sera were read off it. Values at each dilution were expressed as the percentage of the undiluted value, which by definition, equals $100 \%$. Key: O Eli; - Hae; $\triangle \mathrm{Har} ; \triangle \mathrm{Az} ; \square \mathrm{Fs}$

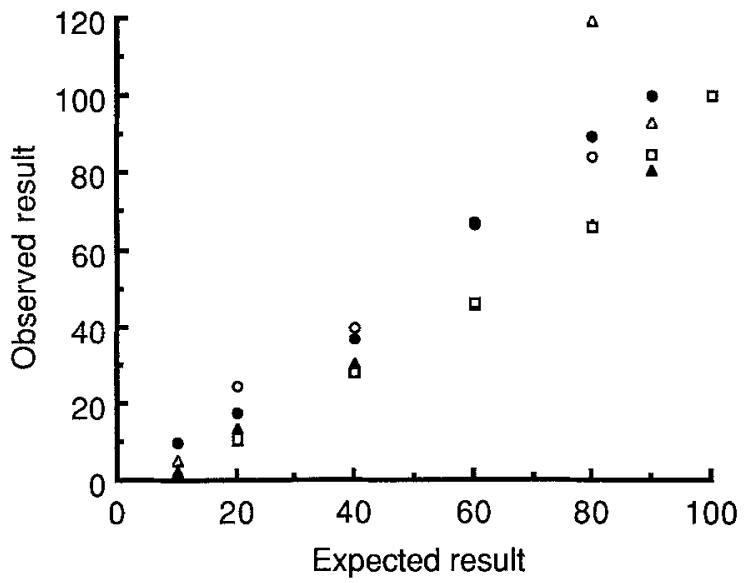

Fig. 2. Dilution curves were constructed for five sera using Elisa. Symbols below refer to the various patient sera followed by name abbreviation. One serum was selected as a standard and the others were read off it. Key: O Eli; $-\mathrm{Hae} ; \Delta \mathrm{X} ; \Delta \mathrm{Az} ; \square \mathrm{Ar}$

binding capacity. One serum was from a non-diabetic asymptomatic blood donor. In this serum, IAA were of such low avidity that they could only be detected by ELISA.

\section{$R I A$}

The assay was performed as previously described [20]. The sera were serially diluted in non-immune serum and $50 \mu \mathrm{l}$ samples assayed. Human sequence A-14 125 -I insulin (specific activity $260 \mathrm{mCi} / \mathrm{mg}$ ) was used with $20,000 \mathrm{cpm}$ per tube. The incubation volume was $350 \mu \mathrm{l}$, the incubation time $72 \mathrm{~h}$ at $4^{\circ} \mathrm{C}$ and the separation procedure was with polyethylene glycol $6000150 \mathrm{~g} / 1$. The results were expressed as the percentage of the labelled insulin bound.

\section{ELISA}

ELISA of insulin IgG (AI-IgG) was performed as previously described [8]. Microplates (Nunc, 4-39454, Gibco, Paisley, UK) were coated with $1 \mu \mathrm{g} / 75 \mu \mathrm{l}$ solution of insulin (bovine and human crystal- lized insulins were a generous gift from Novo Industri AS, Copenhagen, Denmark).

Standard curves were performed as follows: $0-10-20-40-60$ $80-90-100 \%$ of sample containing AI-IgG diluted in antibody free serum. Each curve was diluted with phosphate buffered saline (PBS) $\left(\mathrm{NaH}_{2} \mathrm{PO}_{4} \cdot 2 \mathrm{H}_{2} \mathrm{O} 0.52 \mathrm{~g} / \mathrm{l}, \mathrm{K}_{2} \mathrm{HPO}_{4} \cdot 3 \mathrm{H}_{2} \mathrm{O} 3.67 \mathrm{~g} / \mathrm{l}, \mathrm{NaCl} 8.76 \mathrm{~g} / \mathrm{l}\right.$, bovine serum albumin $2 \mathrm{~g} / 1$ and Tween $200.5 \mathrm{ml} / 1$; $\mathrm{pH}=7.2$ ) to obtain an optical density (OD) between 1.5 and $2.0 \mathrm{U}$ as ' $100 \%$ '. Fifty microlitre samples were used; as a blank, instead of serum, buffer was added to one well per row. After $2 \mathrm{~h}$ incubation at $37^{\circ} \mathrm{C}$ and three successive washes with the buffer, a mouse monoclonal antihuman $\operatorname{IgG}$ was added (MH 001, Gamma s.a., Sart Tilman, Liège, Belgium). After a second $2 \mathrm{~h}$ incubation at $37^{\circ} \mathrm{C}$ and after three washes, a rabbit anti-mouse Ig serum conjugated to peroxidase (P260, Dako, Glostrup, Denmark) was allowed to react for $1 \mathrm{~h}$ at $37^{\circ} \mathrm{C}$. After four washes with tap water, 2.2'-azino-di-(3-ethylbenzthiazolinsulfonate 6) (ABTS, Boehringer, Mannheim, FRG) was added and the oxidised chromogen was measured by reading absorbance at $405 \mathrm{~nm}$.

\section{Dissociation}

Dissociation of preformed immune complexes was performed as previously described [21]. Purified bovine and human insulins $(0.1 \mathrm{mg}$; Novo, Copenhagen, Denmark) were labelled with Na 125 I and the species which was monoiodinated on Tyr A14 was purified by reverse phase HPLC [22, 23].

Serum samples were incubated overnight at $4^{\circ} \mathrm{C}$ with an equal volume of $125-\mathrm{I}$ insulin (specific activity $300 \mathrm{mCi} / \mathrm{mg}, 20,000 \mathrm{cpm} /$ $0.1 \mathrm{ml}$ ). At time 0 they were mixed with dextran coated charcoal (one volume of charcoal suspension, $50 \mathrm{mg} / \mathrm{ml}$ in PBS, and one volume of dextran $T 705 \mathrm{mg} / \mathrm{ml}$ in PBS) and were then continuously stirred, using a magnetic 'flea', at $20^{\circ} \mathrm{C}$. At selected times duplicate aliquot samples were drawn and immediately centrifuged to separate antibody-bound and free hormone. The radioactivity in the supernatant and in the pellet were counted and the percentage of antibody-bound $125 \mathrm{I}$ insulin (supernatant) was calculated and plotted against time.

\section{ELISA competition}

A serum dilution yielding an OD between 1.5 and $2.0 \mathrm{U}$ was chosen for ELI and for X. Samples, diluted accordingly, were preincubated overnight at $4^{\circ} \mathrm{C}$ with increasing amounts of human or bovine insulins $(0.025 \mu \mathrm{g} / \mathrm{ml}$ to $200 \mu \mathrm{g} / \mathrm{ml})$. Fifty microlitres of preincubated samples were tested on insulin coated plates. The following methodological steps: antihuman IgG mouse monoclonal antibody, peroxidase conjugated anti-mouse $\mathrm{IgG}$ rabbit serum and finally, $\mathrm{H}_{2} \mathrm{O}_{2}$ and chromogen were performed as described under the ELISA heading.

Table 1. Set values for low and high affinity insulin antibodies and accordingly calculated values for total insulin concentration

\begin{tabular}{lll}
\hline & $\begin{array}{l}\text { Insulin antibody } \\
\text { high affinity }\end{array}$ & $\begin{array}{l}\text { Insulin autoantibody } \\
\text { low affinity }\end{array}$ \\
\hline Association constant; & $1 \times 10^{9}$ & $1 \times 10^{7}$ \\
l/mol & $6.7 \times 10^{-11 \mathrm{a}}$ & $6.7 \times 10^{-11 \mathrm{a}}$ \\
Free insulin $\mathrm{mol} / \mathrm{1}$ & $1 \times 10^{-7}$ & $1 \times 10^{-7}$ \\
Total antibody $\mathrm{mol} / 1$ & $6.3 \times 10^{-9}$ & $1.3 \times 10^{-10}$ \\
Total insulin $\mathrm{mol} / 1$ &
\end{tabular}

${ }^{a}$ equal to $10 \mathrm{mU} / 1$ 


\section{Mathematical modelling}

The formulae used to model RIA were derived from the Law of Mass Action:

$\mathrm{Ka}=[\mathrm{Ab} . \mathrm{Ag}] /[$ Free $\mathrm{Ab}] \times[$ Free $\mathrm{Ag}]$

for the reversible reaction

Free $\mathrm{Ab}+$ Free $\mathrm{Ag}<>\mathrm{Ab} . \mathrm{Ag}$

where $\mathrm{Ka}=$ affinity constant

$\mathrm{Ag} \quad=$ antigen

$\mathrm{Ab}=$ antibody

$\mathrm{Ab} . \mathrm{Ag}=$ immune complexes

The hypothetical performance of low and high affinity sera in this assay was examined. In these sera the variables were the concentration of antibody and the affinity of the antibody. The antibody was assumed to be 'monoclonal' in order to define a single value for affinity. The free insulin concentration was fixed at a physiologically acceptable level $(67 \mathrm{pmol} / \mathrm{l} ; 10 \mathrm{mU} / \mathrm{l})$ and the total insulin in the sera calculated from the formula:

$[\mathrm{Ag}]=[$ Free Ag] $\{1+[\mathrm{Ab}] /[1 / \mathrm{Ka}]+[$ Free Ag] $\}$

Set and calculated values used for mathematical modelling are summarized in Table 1.

For RIA the concentration of radiolabelled ligand was taken as $20 \mathrm{pmol} / \mathrm{I}$ and the fraction of label bound $\left[\mathrm{B}_{\mathrm{Ag}}\right]$ at various dilutions of serum calculated from the formula:

$\mathrm{B}_{\mathrm{Ag}}=1 / 2\left\{[\mathrm{Ab} / \mathrm{Ag}+1+1 / \mathrm{KAg}]-\left[(\mathrm{Ab} / \mathrm{Ag}+1+1 / \mathrm{KAg})^{2}-4(\mathrm{Ab} / \mathrm{Ag})^{0.5}\right\}\right.$

RIA curves were plotted as $\mathrm{B}_{\mathrm{Ag}}$ against antibody dilution.

For ELISA the amount of insulin on the well surface was taken as $200 \mathrm{ng}$; this was derived from the insulin concentration producing $50 \%$ inhibition in the ELISA competition assay. Previously, we experimentally measured that coated insulin was $140 \mathrm{ng}$ [8]. The amount of antibody bound to the well $B_{A b}$ at various dilutions of serum cannot be calculated using a rearrangement of the above formula.

In ELISA the Law of Mass Action cannot be used because coated antigen and detected antibodies exist on the solid phase and free antibodies exist in the liquid phase. The amount of bound antibody is calculated from the formula: $B_{A b}=f\left(Q_{A b}\right)$ where $Q_{A b}$ is the initial amount of antibody in liquid phase.

ELISA curves were plotted as $\mathbf{B}_{\mathrm{Ab}} \mathrm{x}$ constant against the antibody dilution; the constant was introduced so that the OD was approximately 2 for undiluted antiserum.

\section{Results}

In the RIA there was for each IA serum, as expected, a proportionality between the binding of labelled insulin and the amount of serum present at each dilution. However, the one serum which contained IAA did not bind labelled insulin at any dilution. Binding-dilution curves could be constructed for each of the other sera; however, the slopes of the curves differed. One serum was used as a standard and given an arbitrary value of $100 \mathrm{U} / 1$. All the other samples were read off this standard curve and given values in $\mathrm{U} / \mathbf{l}$. For diluted sera the observed values did not agree with the values expected from dilution. Each undiluted test serum was alotted a value of $100 \%$ and values at each dilution were expressed as the percentage of the undiluted value (Fig. 1). Depending on the standard sera selected, the observed values could be above or below the expected value.

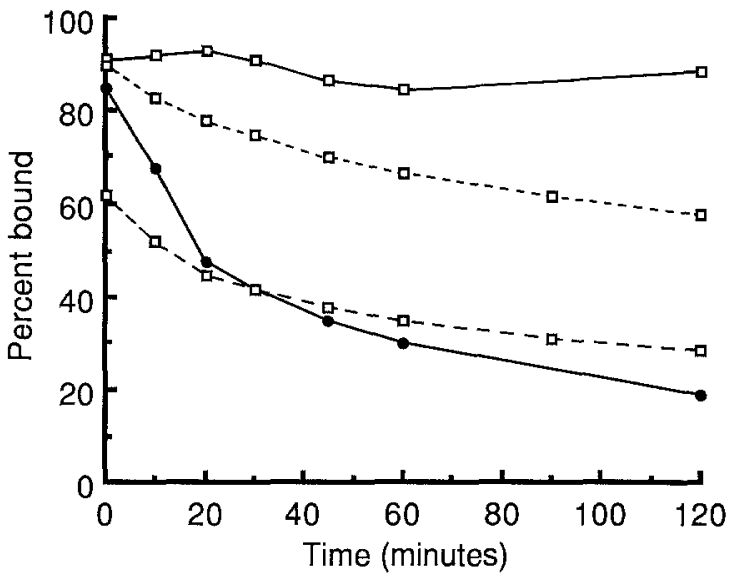

Fig.3. Dissociation of immune complexes for three sera, using 125 Ilabelled bovine insulin. In subject Eli both bovine and human insulin were used as tracers. Symbols refer to patient sera-insulin complex. Key: $\square \longrightarrow \square$ Eli-bovine; $\longrightarrow$ Eli-human; $\square---\square$ Gia-bovine; $\square--\square$ Hae-bovine

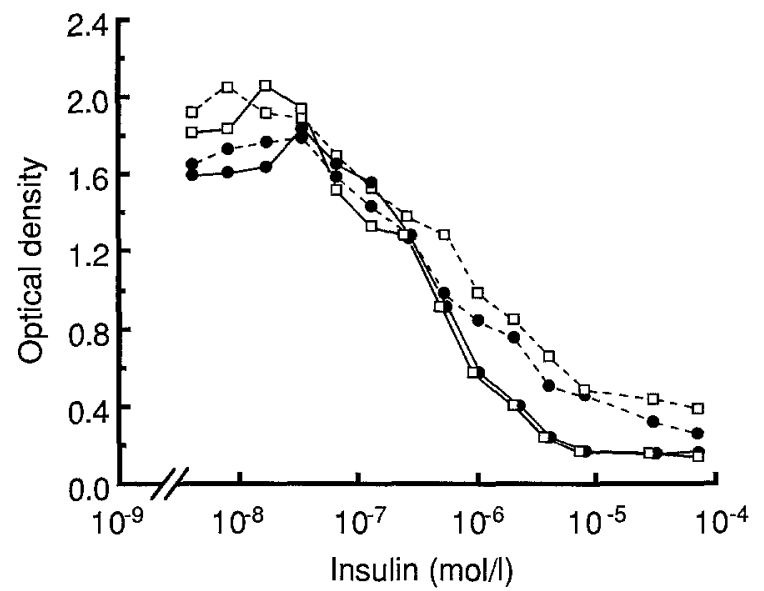

Fig.4. Competitive inhibition of binding using both bovine and human insulins as competitors. Symbols refer to patient sera-insulin complex. Plates were coated with human insulin. Key: $\square-\square$ Elibovine; - Eli-human; $\square---\square$ X-bovine; ---1 X-human

The same analytical procedure was followed with the results of ELISA. Standard curves were also obtained for each serum, but in this system all the dilution curves were parallel. Using any serum as a reference the observed values, for diluted samples, agreed with the expected values (Fig. 2). The serum containing IAA gave comparable results to the sera containing IA.

Dissociation curves of preformed immune complexes were curvilinear because of the presence of antibodies with a range of dissociation rates, as expected in polyclonal sera.

Preformed immune complexes made with the IA of the insulin-resistant patient and labelled bovine insulin dissociated very slowly (only $50 \%$ dissociation at $6 \mathrm{~h}$ ); dissociation was much more rapid when the complexes were made with human labelled insulin $(50 \%$ dissociation at $30 \mathrm{~min}$ ). The dissociation rates of the other immune complexes which were studied were intermediate 


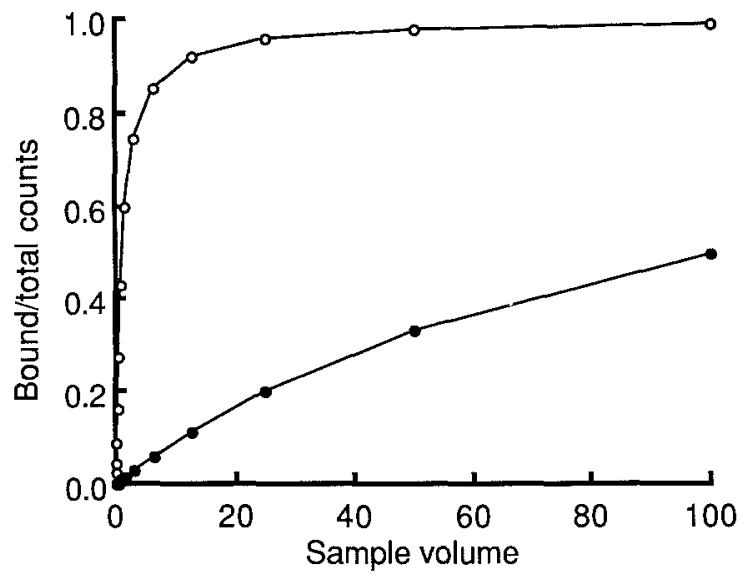

Fig.5. Computer modelling derived standard curves for the liquidphase assay using either a low or high affinity antibody. Key: $O$ High affinity; Low affinity

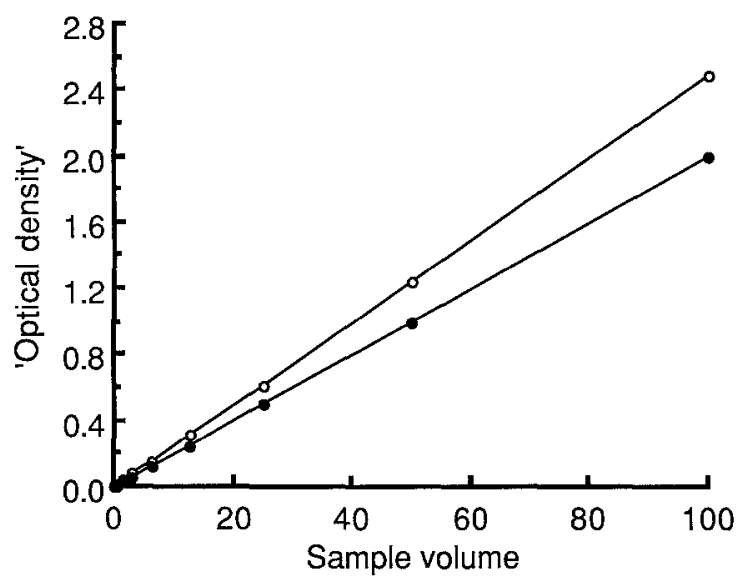

Fig. 6. Computer modelling derived standard curve for the ELISA, using either a low or high affinity antibody. Key: O High affinity; - Low affinity

(Fig. 3). The IAA serum could not be studied in this way because it did not form detectable complexes with radiolabelled insulin; this antibody with extremely low avidity for insulin was studied using preincubation with graded amounts of insulin followed by ELISA and the results compared with the IA from the insulin-resistant patient which showed the highest avidity. Both bovine and human insulins were used as competitors and as the coating antigen. As shown in Figure 4 there was no difference related to the insulin species and very little difference related to the enormous difference in avidity. The displacement curves are clear evidence of the insulin-specificity of both sera.

The mathematical models were created using the parameters shown in Table 1.

Curves representing RIA and ELISA outcomes are shown in Figures 5 and 6 . The binding curves are very different in the RIA but nearly identical in the ELISA. In the ELISA $99.8 \%$ of the high affinity "IA" and $83.3 \%$ of the low affinity "IAA" bound to the insulin coated plate; during dilution the fraction of bound antibody remains nearly constant.

\section{Discussion}

This study demonstrates that major differences exist between the two assay systems commonly used to measure IA. RIA is in particular very sensitive to the avidity or affinity of the antibody; high avidity antibodies can be easily detected and studied with regard to epitope specificity, association and dissociation rates etc., while very low avidity antibodies may not be detected at all. The selectivity of the assay to the avidity of the antibody precludes the use of one serum as a reference for others; indeed, if slow dissociating high avidity antibody is taken as a reference low avidity antibody will be underestimated and vice versa. This observation fits with the Law of Mass Action in that the concentration of labelled insulin is very small which makes the fraction of bound ligand very much dependent on $K$. The extraction of endogenous insulin cannot rectify this problem.

In contrast, ELISA is sensitive to only a very limited degree to the affinity or avidity of the antibody. This means that the fraction of antibody bound at any particular dilution is, theoretically at least, constant. Low avidity antibodies can be detected more readily than with RIA; very low avidity antibodies can only be detected with ELISA. Differences in affinity as may exist for different species of insulin may be more difficult to detect with ELISA. The lack of differentiation to avidity offers ELISA the advantage that a standard reference serum can appropriately be used; this would clearly be an advantage in interlaboratory studies.

Acknowledgements. We are grateful to Prof. R. Ekins for advice about the mathematical modelling. We are also grateful for financial support from the FRSM (Brussels, Belgium), the trustees of the CHU (Liege, Belgium) and of the Middlesex Hospital. Financial support from Nordisk UK and Novo (Copenhagen) is also acknowledged. N. Dozio was supported in part by the Istituto Scientifico San Raffaele (Milan). The authors are grateful to Mrs. M. Hoste-Fodor for secretarial assistance.

\section{References}

1. Banting FG, Franks WR, Gairns S (1938) Physiological studies in metrazole shock. VII. Anti-insulin activity of serum of insulin treated patients. Am J Psychol 95: 562-566

2. Kahn CR, Rosenthal AS (1979) Immunologic reactions to insulin: insulin allergy, insulin resistance, and the autoimmune insulin syndrome. Diabetes Care 2: 283-295

3. Berson SA, Yalow RS (1959) Quantitative aspects of the reaction between insulin and insulin-binding antibody. J Clin Invest 38: 1996-2016

4. Christiansen AH (1970) A new method for determination of insulin-binding immuno-globulins in insulin-treated diabetic patients. Horm Metab Res 2: 187-188

5. Telford ME, Wisdom GB (1979) Enzyme-immunoassay of anti(bovine insulin) antibodies. Biochem Soc Trans 7: 527-529

6. Nell LJ, Virta VJ, Thomas JW (1985) Application of a rapid enzyme-linked immunosorbent microassay (ELISA) to study human anti-insulin antibody. Diabetes 34: 60-66 
7. Wilkin T, Nicholson S, Casey C (1985) A micro enzyme-linked immunosorbent assay for insulin antibodies in serum. $\mathrm{J}$ Immunol Meth 76: 185-194

8. Koch M, Francois-Gerard C, Sodoyez-Goffaux F, Sodoyez JC (1986) Semi-quantitative assessment of antiinsulin total $\mathrm{IgG}$ and IgG subclasses in insulin-immunised patients using a highly sensitive immunochemical micromethod. Diabetologia 29: 720-726

9. Palmer JP, Asplin CM, Clemons P, Lyen K, Tatpati O, Raghu FK, Paquette TL (1983) Insulin antibodies in insulindependent diabetics before insulin treatment. Science 222: 1337-1339

10. Arslanian SA, Becker DJ, Rabin B, Atchison R, Eberhardt M, Cavender D, Dorman J, Drash AL (1985) Correlates of insulin antibodies in newly diagnosed children with insulin-dependent diabetes before insulin therapy. Diabetes 34:926-930

11. Dean BM, Becker F, McNally JM, Tarn AC, SchwartzG, Gale EAM. Bottazzo GF (1986) Insulin autoantibodies in the prediabetic period: correlation with islet cell antibodies and development of diabetes. Diabetologia 29: 339-342

12. Ichihara K, Shima K, Saito Y, Nonaka K, Tarui S, Nishikawa M (1977) Mechanism of hypoglycemia observed in a patient with insulin autoimmune syndrome. Diabetes 26: 500-506

13. Hirata Y (1983) Methimazole and insulin autoimmune syndrome with hypoglycaemia. Lancet II: 1037-1038

14. Benson EA, Healey LA, Barron EJ (1985) Insulin antibodies in patients receiving penicillamine. Am J Med 78: 857-860

15. Trenn G, Eysselein V, Mellinghoff HU, Muller R, Benker G, Reinwein D, Federlin K (1986) Clinical and biochemical aspects of the insulin autoimmune syndrome (IAIS). Klin Wochenschr 64: 929-934

16. Faguer B, Burgard M, Boitard C, Desplanque N, Fanjoux J, Tchobroutsky G (1986) Syndrome hypoglyçémique d'origine autoimmune. Journ Annu Diabetol Hotel Dieu, pp 165-172

17. Sklenar I, Wilkin TJ, Diaz JL, Erb P, Keller U (1987) Spontaneous hypoglycemia associated with autoimmunity specific to human insulin. Diabetes Care 10:152-159
18. Wilkin T, Palmer J, Bonifacio E, Diaz JL, Kruse V (1987) On behalf of the immunology and diabetes workshop and participating laboratories. Workshop report First International Workshop on the Standardization of Insulin Autoantibodies. Diabetologia 30: 676-677

19. Sodoyez-Goffaux F, Koch M, Dozio N, Brandenburg D, Sodoyez JC (1988) Advantages and pitfalls of radioimmune and enzyme linked immunosorbent assays of insulin antibodies. Diabetologia 31: 694-702

20. Kurtz AB, Matthews JA, Mustaffa BE, Daggett PR, Nabarro JDN (1980) Decrease of antibodies to insulin, proinsulin and contaminating hormones after changing treatment from conventional beef to purified pork insulin. Diabetologia 18: 147-150

21. Sodoyez-Goffaux F, Sodoyez JC, Koch M, Dozio N, Arquilla ER, McDougall B, De Vos CJ, von Frenckell R (1987) Scintigraphic distribution of complexes of antiinsulin antibodies and ${ }^{123}$ I-insulin. In vivo studies in rats. J Clin Invest 80:466 474

22. Markussen J, Larsen UD (1980) The application of HPLC to the analysis of radio-iodinated tracers of glucagon and insulin. In: Brandenburg D, Wollmer A (eds) Insulin, chemistry, structure and function of insulin and related hormones. W. De Gruyter, Berlin, pp 161-168

23. Sodoyez JC, Sodoyez Goffaux F, Guillaume M, Merchie G (1983) (123-I) Insulin metabolism in normal rats and humans: external detection by a scintillation camera. Science 219: 865-867

Received: 23 January 1989;

and in revised form: 13 July 1989

Dr. J.C. Sodoyez

Department of Internal Medicine

CHU-Sart Tilman

B-4000 Liege

Belgium 